\title{
Effects of Organic Fertilizer on Soil Characters, Maize Growth and Grain Yield
}

\author{
I Nyoman Adijaya ${ }^{1}$, I Gusti Komang Dana Arsana ${ }^{1}$, Ni Luh Gede Budiari ${ }^{1}$, Made Jana \\ Mejaya $^{2 *}$ \\ ${ }^{1}$ Bali Agricultural Technology Assessment Institute, Indonesia. \\ ${ }^{2}$ Indonesian Legume and Tuber Crops Research Institute, Indonesia.
}

*Corresponding Authors: Made Jana Mejaya, Bali Agricultural Technology Assessment Institute, Indonesia.

\begin{abstract}
Maize demand in Bali was supplied from other provinces because productivity was low at around 3,0 tons $h^{-1}$. Thisassessmenthave been conducted in Sanggalangit Village, Gerokgak Districts, Buleleng,Bali from January to March 2010. The research was designed with factorial randomized block design, three replications. Two treatments were tested namely cow manure dosage: 0 tha ${ }^{-1}, 5$ tha $a^{-1}, 10$ tha $a^{-1}$ and 15 tha ${ }^{-1}$; bio urine dosages: O liter ha $a^{-1}, 25.000$ liters $\mathrm{ha}^{-1}, 50.000$ liters $\mathrm{ha}^{-1}$ and 75.000 liters $\mathrm{ha}^{-1}$, so there were 16 treatment combinations. Increasing dosage of cow manure reduced the bulk density of from 1.23 to 1.16, increased soil moisture content from $31.11 \%$ to $35.17 \%$ and increased total soil pore space from $53.64 \%$ to $56.23 \%$, increased C-organic from $0.27 \%$ to $1.67 \%$. Interaction between cowmanure and bio urine increased $N$-total up to $36.22 \%$, with linear equation $Y=2.049+7.16 \times 10^{-2}$ Manure $+1,26 \times 10^{-5} U\left(R^{2}=0.862 * *\right)$ to dry grain yield so that optimum dosage has not been obtained.
\end{abstract}

Keywords: organic fertilizer, soil character, growth and yield, maize

\section{INTRODUCTION}

In Indonesia, maizeis the second most imporplantt food commodity after rice. Suastikaet al. ${ }^{1}$ stated that the demand for maize from year to year continues to increase, especially for food. Data from 1995 showed that $63 \%$ of maize needs were used for food, $30.5 \%$ for animal feed and the rest was for industrial needs. Muhammad and Akuba ${ }^{2}$ stated that Indonesia's maize production was estimated to increase by $4 \%$ per year in 2005-2010. The use of maize for feed increased $4.9 \%$, for food increased $2 \%$, while the use of maize for industry increased by $3 \%$. Increased maize production was not expected to offset consumption demand until 2010. Supply in 2010 was estimated at 9.9 million tons while demand reaches 15.9 million tons.Potential demand for maize in 2005 in Bali was 209,093 tons $^{3}$, while maize production in Bali was 88,692 tons, therefore, Bali still lacked of maize by approximately 120,401 tons $^{4}$.

Maize productivity in Bali from 2003 to 2007 was still very low, ranging from $2.65-3.00$ tons ha ${ }^{-1}$, by which the Buleleng Regency had the highest planting areacompared to other Regencies ${ }^{4}$. Agung et al. ${ }^{5}$ added to the maize farming in Patas Village, GerokgakDistricts, Buleleng Regency, farmers generally use local varieties that have adapted well to local conditions but their production was generally low. The level of production produced was approximately $3.0 \mathrm{t} \mathrm{ha}^{-1}$ dry shelled. The planting area of maize in GerokgakDistricts in 2008 was 7,207 hectweres with a production of 23,055 tons of dry grain, so that the productivity was 3.20 tons ha ${ }^{-16}$. Low land fertility was one of the causes of low maize production ${ }^{1}$. The production constraints were partly due to the poor soil physical properties and soil stability in macro and micro elements, thereby reducing land productivity ${ }^{7}$.

$\mathrm{N}$ ijManure was one source of soil organic matter which is very usefull in improving physical, chemical and biological soil properties. Manure can increase $\mathrm{pH}$, levels of C-organic and increase the availability of nitrogen, phosphorus, potassium and micro-elements for plants ${ }^{8,9}$. Kuntyastuti and Rahmiana ${ }^{10}$ stated that the use of organic fertilizer in an effort to increase land productivity requires quite high amounts of fertilizer, so that it becomes a limiting factor in large-scale alpication. To overcome this high amounts of manure required, the use of bio urine may be one choice in large-scale microorganisms)as. 
Bio urine isproduced by fermenting animal urine ${ }^{11}$. To process the waste from cow manure (urine) into more useful and potentially useful products, a fermentation technology package is needed by involving the role of bacteria (microorganwasms) to convert or transform chemical compounds to organic substrates so that they can be implemented directly as nutrients in agricultural crops $^{12}$.Utilization of urine or bio urine for fertilizing plants was still very rarely applied. Adijaya ${ }^{13}$ obtained the utilization of 7,500 liters ha ${ }^{-1}\left(1 \mathrm{ha}^{-1}\right)$ of cow urine combined with $5.0 \mathrm{t} \mathrm{ha}^{-1}$ cow manure was able to increase the yield of shallots by $60.77 \%$, while the application of cow's urine $15,0001 \mathrm{ha}^{-1}$ increased yield by $31.72 \%$ compared with no fertilization which resulted in a tuber of $6.45 \mathrm{t} \mathrm{ha}^{-1}$.

Information about the results of cow manure and bio urine research was still very limited, therefore, research on this aspect needs to be done on maize plants which was one of the most widely cultivated plants in dry land.

\section{MATERIALS AND MethodS}

Thisresearch was a field trial, carried out in the dry land of Sanggalangit Village, GerokgakDistricts, Buleleng Regency, Bali Province, Indonesia with rainfall of 1,200 mm - 1,400 mm year ${ }^{-1}$ and altitude $+50 \mathrm{~m}$ above sea level (ASL). The research was conducted from January 3 to March 22, 2010. The results of the soil analysis of the test site showed low N-total and C-organic soil, i.e $0.110 \%$ and $1.03 \%$. The research was arranged in factorial randomized block design (RBD) with 3 replications. Two treatments tested, namely dosage of animal manure and bio-urine dosage of cow, each consisted of 4 levels, resulted in 16 total combination treatments. The dosage treatments of tested cow manure dosage consisted of 4 levels, namelye: $\mathrm{M}_{0}=$ Cow manure $0 \mathrm{t} \mathrm{ha}^{-1}$ (without cow manure), $\mathrm{M}_{1}=$ Cow manure $5 \mathrm{tha}^{-1}, \mathrm{M} 2=$ Cow manure $10 \mathrm{t} \mathrm{ha}^{-1}$, and M3 = Cow manure $15 \mathrm{t} \mathrm{ha}^{-1}$. Treatment of cow's biourine dosage consisted of 4 levels, namely: U0 = Bio-urine of cow 01 ha $^{-1}$, U1 = Bio-urine of cow 25,000 $1 \mathrm{ha}^{-1}, \mathrm{U} 2=$ Bio-urine of cow 50,000 $1 \mathrm{ha}^{-1}$, and U3 = Bio-urine of cow 75,000 $1 \mathrm{ha}^{-1}$.

Cow manure was analyzed at the Department of Soil Laboratory, Faculty of Agriculture, Udayana University, 2007, while cow urine urine was analyzed at the Bogor Soil Research Institute, 2007. Data analysis of cow manure and bio-urineare presented atTable 1.

Table1. Analysis of cow manure and bio-urine

\begin{tabular}{|l|l|l|}
\hline Type ofAnalysis & CowManure & Cow Bio-Urine \\
\hline $\mathrm{pH}$ & 7.90 & 8.50 \\
\hline C-organik (\%) & 23.75 & 0.49 \\
\hline N total (\%) & 1.78 & 0.18 \\
\hline P available (ppm) & 79.64 & 76.00 \\
\hline K avaailable (ppm) & 9616.68 & 5974.00 \\
\hline Ca (ppm) & & 24.00 \\
\hline Mg (ppm) & & 274.0 \\
\hline
\end{tabular}

The maizeseeds used in this research wasSeraya Local varieties. Soil processing was carried out 2 times. In the second tillage, plots of $3.60 \mathrm{~m}$ x $4.00 \mathrm{~m}$ were formed. The displantce between treatment plots was $0.5 \mathrm{~m}$ and the displantce between replications was $1.0 \mathrm{~m}$. Plantingwas done by using three to three grain per hole with a spacing of $60 \mathrm{~cm}$ x $40 \mathrm{~cm}$, leaving 2 plants per planting hole.

The treatment of cow manure that has been fermented (ripe) was given one week before planting according to treatment. Fertilization with bio-urine of cowwas given 4 times each $1 / 4$ dose, namely at the age of 14, 28, 42 and 56 days after planting by splashing near the base of the plant according to the treatment dose. The volume of bio-urine of cow that were given were respectively 01 of clump $^{-1}$ (bio-urine of cow $01 \mathrm{ha}^{-1}$ ), $0.151 \mathrm{of} \mathrm{clump}^{-1}$ (bio urine of 25,000 $1 \mathrm{ha}^{-1}$ ), $0.301 \mathrm{of} \mathrm{clump}^{-1}$ (bio-urine of $50,0001 \mathrm{ha}^{-1}$ ) and 0.451 of clump (bio urine of 75,000 $1 \mathrm{ha}^{-1}$ ) for each treatment. Giving cow bio urine with a concentration of $20 \%$ ( 1 liter of urine: 4 liters of water). Weeding was done at the age of plants 21 and 42 days after planting. Harvesting was done at the age of 80 days after the cob has been dried, $75 \%$ of the leaves of the plant have yellowed and dried, the grainwere dense, shiny and if pressed feels hard. Observations were made on the physical and chemical properties of the soil as well as the growth and yield of maize.

\subsection{Soil Physical Properties}

Soil physical properties observed were weight of soil volume, soil moisture content and total pore space, with the following mechanism: 
1. Bulk volume weight $\left(\mathrm{g} \mathrm{cm}^{-3}\right)$

Observation of plant age 42 days after planting and at harvest timewas done by taking soil samples in the field using a sample ring at a depth of $0 \mathrm{~cm}-10 \mathrm{~cm}$. Weight of soil volume was calculated by the formula:

Weight of oven dry soil (g)

Soil volume weight $=$

( $\mathrm{g} \mathrm{cm}-3)$

Soil volume $(\mathrm{cm} 3)$

2. Soil water content (\%)

Soil water observations were carried out using gravimetric method ${ }^{14}$, namely at plant age 42 days after planting and at harvest time. Soil water content was calculated using the formula:

Wet soil weight (g) - Oven dry soil weight $(\mathrm{g})$

Soil water content $(\%)=$ $\mathrm{x} 100 \%$

Weight of oven dry soil $(\mathrm{g})$

3. Total pore space $(\%)$

Measurements were calculated based on the results of determining the soil volume weight (bulk density) and soil particle density $(2.65 \mathrm{~g} \mathrm{~cm}-3)^{15}$. The measurement of pore space was carried out at 42 days after planting and at harvest timewith the equation:

$\mathrm{f}=(1.0-\mathrm{b} / \mathrm{p}) \times 100 \%$

Where: $\mathrm{f}=$ total pore space $(\%), \mathrm{b}=$ soil volume weight $\left(\mathrm{g} \mathrm{cm}^{-3}\right), \mathrm{p}=$ soil particle density by assumption of $2.65 \mathrm{~g} \mathrm{~cm}^{-3}$.

\subsection{Soil Chemical Properties}

Observations on the soil chemical properties were carried out on total $\mathrm{N}, \mathrm{C}$-organic and soil $\mathrm{pH}$ at harvest. Determination of total $\mathrm{N}$ and $\mathrm{C}$-organic soil was done by taking soil samples from each treatment plot of $500 \mathrm{~g}$ and then dried, fine sifted and analyzed in a laboratory. The method used for the determination of the $\mathrm{N}$-total was the Kjeldahl method while the C-organic was the Walkey and Black method.

\subsection{Maize Growth and Yield}

The agronomic parameters observed were growth components (plant height, number of leaves plant ${ }^{-1}$, leaf area index (LAI), and oven dry weight with plant ${ }^{-1}$ and ha ${ }^{-1}$ sequences) and yield components (oven dry grain weight and grain weight $12 \%$ plant $^{-1}$ ) and ha ${ }^{-1}$ production (oven-dried grain and $12 \%$ $\mathrm{ha}^{-1}$ grainmoisture content) and harvest index. Data were analyzed for variance, if the interaction between dosage of manure and bio urine significantly affected continued with the Duncan test level of $5 \%$, if the single treatment with significant effect was followed by LSD test level of $5 \%{ }^{16}$.

\section{RESULTS AND DISCUSSION}

\subsection{Soil Physical Properties}

Application of cow manure alone has a significant effect on the physical properties of the soil of the trial location such as reducing the weight of the soil volume (bulk density), increasing the water content and the total pore space of the soil at harvest. Bulk density significantly decreased with the application of $15 \mathrm{t} \mathrm{ha}^{-1}$ cow manure, from $1.23 \mathrm{~g} \mathrm{~cm}^{-3}$ to $1.16 \mathrm{~g} \mathrm{~cm}^{-3}$, the water content increased from $31.11 \%$ to $35.17 \%$ and the total soil pore space increased from $53.64 \%$ to $56.23 \%$ (Table 2).

The results of this study were in line with the results of the Suratmini ${ }^{17}$ study which stated that the application of 15 tons of ha ${ }^{-1}$ fertilizer sometimes cow reduced the soil bulk density from $1.00 \mathrm{~g} \mathrm{~cm}^{-3}$ to $0.98 \mathrm{~g} \mathrm{~cm}^{-3}$, increasing the water content from $27.22 \%$ to $29,11 \%$ and increase pore space $62.32 \%$ to $63.09 \%$. Muku ${ }^{18}$ informedthat applied $15 \mathrm{t} \mathrm{ha}^{-1}$ of cow manure fertilizer on onions reduced the soil bulk density from $0.14 \mathrm{~g} \mathrm{~cm}^{-3}$ to $0.12 \mathrm{~cm}^{-3}$ and increased soil moisture content from $15.87 \%$ to $17.52 \%$. Aguset al. ${ }^{19}$ stated that soil bulk volume was one of the most commonly determined physical 
properties of soil, because it was closely related to the ease of root penetration in the soil, drainage and soil aeration.

Table2. Effect of single dose of cow manure and bio urine on soil volume (bulk density), moisture content and total pore space of the soil at harvest

\begin{tabular}{|l|l|l|l|}
\hline \multirow{2}{*}{ Treatments } & Soil bulk density & $\begin{array}{l}\text { Soil moisture } \\
\text { content }\end{array}$ & $\begin{array}{l}\text { Total soil pore } \\
\text { space }\end{array}$ \\
\cline { 2 - 4 } & $\left(\mathbf{g ~ c m}^{-3}\right)$ & $(\%)$ & $(\%)$ \\
\hline Dosage ofcow manure $\left(\mathrm{t} \mathrm{ha}^{-1}\right):$ \\
\hline 0 & $1.23 \mathrm{a}$ & $31.11 \mathrm{c}$ & $53.64 \mathrm{~d}$ \\
\hline 5 & $1.19 \mathrm{~b}$ & $34.06 \mathrm{~b}$ & $55.10 \mathrm{c}$ \\
\hline 10 & $1.18 \mathrm{c}$ & $35.08 \mathrm{ab}$ & $55.56 \mathrm{~b}$ \\
\hline 15 & $1.16 \mathrm{~d}$ & $35.17 \mathrm{a}$ & $56.23 \mathrm{a}$ \\
\hline LSD 5\% & 1.03 & 0.25 \\
\hline Dosage of cow bio urine $\left(\mathrm{l} \mathrm{ha}^{-1}\right):$ & 0.02 & $33.67 \mathrm{a}$ & $55.01 \mathrm{a}$ \\
\hline 0 & $1.19 \mathrm{a}$ & $34.17 \mathrm{a}$ & $55.19 \mathrm{a}$ \\
\hline 25,000 & $1.19 \mathrm{a}$ & $33.79 \mathrm{a}$ & $55.14 \mathrm{a}$ \\
\hline 50,000 & $1.19 \mathrm{a}$ & $33.80 \mathrm{a}$ & $55.19 \mathrm{a}$ \\
\hline 75,000 & $1.19 \mathrm{a}$ & - & - \\
\hline LSD 5\% & - &
\end{tabular}

Note: Figures for the same treatment and column followed by the same letter were not significantly different at the $5 \%$ LSD test.

\subsection{Soil Chemical Properties}

Soil N-totalcontent levels at harvest increased as a result of the interaction of manure with cow's biourine (Table 3). These results were in line with the results of the study by Syukur and Harsono ${ }^{20}$, which obtained an increase in fertilizer manure up to a dose of $30 \mathrm{t} \mathrm{ha}^{-1}$ significantly increased the total $\mathrm{N}$-level from $376.67 \mathrm{ppm}$ to $474.00 \mathrm{ppm}$ and $\mathrm{N}$-available soil from $10.65 \mathrm{ppm}$ to $11.14 \mathrm{ppm}$.

Soil N-total content of the study site before treatment was low, that was $0.11 \%$. Sirappa ${ }^{21}$ stated that the critical nitrogen limit for maize plants was $0.15 \%$. If the nitrogen content in the soil was lower than the critical limit, the maize plant will be very responsive to the nitrogen fertilization. The higher levels of nitrogen in the soil cause the nitrogen available to plants will increase, so that plant growth will be increasingly encouraged. Thiswasdue to the function of nitrogen which gives the fastest effect on plant growth compared to other nutrients. Sutejo ${ }^{22}$ and Poerwowidodo ${ }^{23}$ stated that nitrogen was needed to stimulate vegetative growth, to increase chlorophyll increasing the size of leaves and grain. Lack of nitrogen will reduce the amount of chlorophyll in the leaves, which causes the rate of photosynthesis to decrease so that the resultedphotosynthate decreases.

Table3. Effects of interactions between dosage of manure and bio-urine of cow on total $N$-soil at harvest

\begin{tabular}{|c|c|c|c|c|}
\hline \multirow{2}{*}{ Treatments } & \multicolumn{4}{|c|}{ N-total (\%) } \\
\cline { 2 - 5 } & \multicolumn{4}{|c|}{ Dosage of cow manure (t ha $\left.\mathbf{~}^{-1}\right)$} \\
\cline { 2 - 5 } & $\mathbf{0}$ & $\mathbf{5}$ & $\mathbf{1 0}$ & $\mathbf{1 5}$ \\
\hline Dosage of bio urin $\left(\mathbf{l ~ h a}^{-1}\right)$ & $0.13 \mathrm{c}$ & $0.16 \mathrm{ab}$ & $0.12 \mathrm{c}$ & $0.15 \mathrm{abc}$ \\
\hline 0 & $0.12 \mathrm{c}$ & $0.13 \mathrm{bc}$ & $0.13 \mathrm{bc}$ & $0.14 \mathrm{bc}$ \\
\hline 25,000 & $0.16 \mathrm{abc}$ & $0.14 \mathrm{bc}$ & $0.14 \mathrm{abc}$ & $0.16 \mathrm{ab}$ \\
\hline 50,000 & $0.14 \mathrm{abc}$ & $0.15 \mathrm{abc}$ & $0.17 \mathrm{a}$ & $0.14 \mathrm{abc}$ \\
\hline 75,000 & &
\end{tabular}

Note: Figures for the same treatment and column followed by the same letter were not significantly different in the 5\% LSD test.

C-organic soil at harvest increased due to the sole effect of cow manure and cow bio-urine treatment. Increasing dosage of cow manure to $15 \mathrm{t} \mathrm{ha}^{-1}$ increased the soil C-organic content from $0.27 \%$ to $1.67 \%$ or an increased of $518.52 \%$, while increasing the cow's bio-urine dose to $75,0001 \mathrm{ha}^{-1}$ increased the C-content soil organic matter from $0.75 \%$ to $1.18 \%$ or an increase of $57.33 \%$ (Table 4 ). Gratitude and Indah2 4 who examined the application of $10 \mathrm{t} \mathrm{ha}^{-1}, 20 \mathrm{t} \mathrm{ha}^{-1}$ and $40 \mathrm{t} \mathrm{ha}^{-1}$ cow manure on ginger plants stated that C-organic soil after harvest increased by $12.55 \%, 20.55 \%$, and $36.51 \%$ compared without fertilization (1.59\%). The C-organic content of the soil decreases if fertilization was not carried out with organic fertilizer. At no fertilization the C-organic value was lower than the soil analysis before treatment was carried out from $1.03 \%$ to $0.27 \%$ and $0.75 \%$ (Table 4). Syukur ${ }^{25}$ and 
Syukur and Harsono ${ }^{20}$ stated that the content of C-organic indicates the content of organic matter in the soil where the content of C-organic was approximately $58 \%$ of the soil organic matter. Application of organic fertilizer was needed to maintain and increase the content of C-organic in the soil.The treatment of cow manure and bio urine did not affect the soil $\mathrm{pH}$. The soil $\mathrm{pH}$ range of the test site was 6.82 - 6.87 due to the treatment of cow manure and bio urine (Table 4).

Table4. Effects of single dosage of cow manure and bio-urine on C-organic and soil pH at harvest

\begin{tabular}{|c|c|c|}
\hline Treatments & C- organic $(\%)$ & pH \\
\hline \multicolumn{3}{|c|}{ Dosage of cow manure $\left(\mathrm{t} \mathrm{ha}^{-1}\right)$} \\
\hline 0 & $0.27 \mathrm{~d}$ & $6.87 \mathrm{a}$ \\
\hline 5 & $0.76 \mathrm{c}$ & $6.85 \mathrm{a}$ \\
\hline 10 & $1.26 \mathrm{~b}$ & $6.82 \mathrm{a}$ \\
\hline 15 & $1.67 \mathrm{a}$ & $6.79 \mathrm{a}$ \\
\hline LSD 5\% & 0.24 & - \\
\hline \multicolumn{3}{|c|}{ Dosage of bio urin $\left(\mathrm{l} \mathrm{ha}^{-1}\right)$} \\
\hline 0 & $0,75 \mathrm{c}$ & $6,86 \mathrm{a}$ \\
\hline 25,000 & $0,90 \mathrm{bc}$ & $6,80 \mathrm{a}$ \\
\hline 50,000 & $1,12 \mathrm{ab}$ & $6,85 \mathrm{a}$ \\
\hline 75,000 & $1,18 \mathrm{a}$ & $6,82 \mathrm{a}$ \\
\hline LSD 5\% & 0,239 & - \\
\hline
\end{tabular}

Note: Figures for the same treatment and column followed by the same letter were not significantly different in the 5\% LSD test.

\subsection{Maize Growth and Yield}

The growth component of Serayalocal maize was also significantly affected by manure and bio-urine fertilizer which was marked by an increase in growth components such as plant height, number of leaves, leaf area index (LAI), fresh weight and oven dry weight of biomass (Table 5). The biomass oven dry weight ha $^{-1}$ increased by $37.11 \%$ in fertilizer of $15 \mathrm{t} \mathrm{ha}^{-1}$ cow manure and increased by $22.97 \%$ in fertilizer of 75,000 $1 \mathrm{ha}^{-1}$ bio-urine. The increase in the value of the components of Local Serayamaize was due to the increased production of assimilates compared to without fertilization. The increase in LAI was caused by an increase in the number of leaves, as well as an increase in leaf area. The maximum LAI, which was 49 days after birth, increased from 2.52 to 2.87 due to the influence of a single factor of cow manure and 2.55 to 2.83 due to the influence of a single factor of bio-urine (Table 5).

Table5. Effect of single dose of cow manure and bio urine on plant height, number of leaves, LAI and biomass oven dryweight

\begin{tabular}{|c|c|c|c|c|c|}
\hline \multirow[b]{2}{*}{ Treatments } & \multirow{2}{*}{$\begin{array}{c}\text { Plant } \\
\text { height }(\mathbf{c m})\end{array}$} & \multirow{2}{*}{$\begin{array}{c}\text { Number of } \\
\text { leaves }\end{array}$} & \multirow{2}{*}{$\begin{array}{l}\text { Leaf area } \\
\text { index }\end{array}$} & \multicolumn{2}{|c|}{ Biomass oven dryweight } \\
\hline & & & & $\left(\right.$ g plant $\left.^{-1}\right)$ & $\left(\mathrm{t} \mathrm{ha}^{-1}\right)$ \\
\hline \multicolumn{6}{|c|}{ Dosage of cowmanure $\left(\mathrm{t} \mathrm{ha}^{-1}\right)$} \\
\hline 0 & $297.23 \mathrm{~d}$ & $9.83 \mathrm{~d}$ & $2.52 \mathrm{~d}$ & $42.34 \mathrm{c}$ & $3.53 \mathrm{c}$ \\
\hline 5 & $311.18 \mathrm{c}$ & $10.08 \mathrm{c}$ & $2.67 \mathrm{c}$ & $48.13 \mathrm{~b}$ & $4.01 \mathrm{~b}$ \\
\hline 10 & $316.24 \mathrm{~b}$ & $10.26 \mathrm{~b}$ & $2.77 \mathrm{~b}$ & $52.67 \mathrm{ab}$ & $4.39 \mathrm{ab}$ \\
\hline 15 & $323.53 \mathrm{a}$ & $10.57 \mathrm{a}$ & $2.87 \mathrm{a}$ & $58.05 \mathrm{a}$ & $4.84 \mathrm{a}$ \\
\hline LSD 5\% & 4.81 & 0.11 & 0.05 & 5.48 & 0.46 \\
\hline \multicolumn{6}{|l|}{$\begin{array}{l}\text { Dosage of cow } \\
\text { bio-urine }\left(\mathrm{l} \mathrm{ha}^{-1}\right)\end{array}$} \\
\hline 0 & $299.39 \mathrm{~d}$ & $9.78 \mathrm{~d}$ & $2.55 \mathrm{~d}$ & $44.63 \mathrm{c}$ & $3.70 \mathrm{c}$ \\
\hline 25.000 & $310.39 \mathrm{c}$ & $10.13 \mathrm{c}$ & $2.68 \mathrm{c}$ & $48.41 \mathrm{bc}$ & $4.04 \mathrm{bc}$ \\
\hline 50.000 & $316.68 \mathrm{~b}$ & $10.35 \mathrm{~b}$ & $2.77 \mathrm{~b}$ & $53.80 \mathrm{ab}$ & $4.48 \mathrm{ab}$ \\
\hline 75.000 & $321.76 \mathrm{a}$ & $10.48 \mathrm{a}$ & $2.83 \mathrm{a}$ & $54.63 \mathrm{a}$ & $4.55 \mathrm{a}$ \\
\hline LSD 5\% & 4.81 & 0.11 & 0.05 & 5.48 & 0.46 \\
\hline
\end{tabular}

Note: Figures for the same treatment and column followed by the same letter were not significantly different in the 5\% LSD test.

The increased assimylate production resulted in an increase in the harvest index of $121.39 \%$ in the combined treatment of cow manure with a dose of $15 \mathrm{t} \mathrm{ha}^{-1}$ with bio urine at a dose of 75,000 $\mathrm{l} \mathrm{ha}$ ${ }^{1}$ compared without fertilization (Table 6). Purnomo26 states that if the maize leaf area index was 1.14-2.42, it means that the prediction of intercepted light was $79-89 \%$ so that it still increases the economic yield of the plant so that the harvest index was still increasing. Goldsworthy cit. Fwascher 
and Palmer (1995 in Indradewa et.al. ${ }^{27}$ ), that the optimum leaf area index for grain yields was between 2.5 and 5.0. If the leaf area index was greater than this value, the addition of dry matter produced was mainly buried in the stems.

The increase in the harvest index due to fertilizer manure and bio urine of cowwas caused by the increasing economic results produced. Increasing dosage of cow manure and bio urine increase the weight of grain produced. Itwas indicated by dosage of manure up to $15 \mathrm{t} \mathrm{ha}^{-1}$ and bio urine up to $75,0001 \mathrm{ha}^{-1}$ causing local maize plants as more and more was allocating assimilates to storage organs.

Table5. Effect of interaction between dosage of manure and bio-urine of cow on the weight of the oven dry grain, grain weight at $12 \%$ moisture content and harvest index

\begin{tabular}{|c|c|c|c|c|c|c|}
\hline \multirow[t]{2}{*}{ No. } & \multirow[t]{2}{*}{ Treatments } & \multicolumn{2}{|c|}{$\begin{array}{l}\text { Grainweight at } \\
\text { oven dry }\end{array}$} & \multicolumn{2}{|c|}{$\begin{array}{l}\text { Grain weight at } 12 \% \\
\text { moisture content }\end{array}$} & \multirow{2}{*}{$\begin{array}{c}\begin{array}{c}\text { Harvest } \\
\text { index }\end{array} \\
(\%)\end{array}$} \\
\hline & & plant $^{-1}(g)$ & $h^{-1}(t)$ & plant $^{-1}(\mathrm{~g})$ & $h^{-1}(t)$ & \\
\hline 1 & Manure $_{0}$ Urine $_{0}$ & $19.65 \mathrm{k}$ & $1.64 \mathrm{k}$ & $21.52 \mathrm{j}$ & $1.79 \mathrm{j}$ & $22.58 \mathrm{j}$ \\
\hline 2 & Manure $_{0}$ Urine $_{1}$ & $30.32 \mathrm{j}$ & $2.52 \mathrm{j}$ & $33.14 \mathrm{i}$ & $2.76 \mathrm{i}$ & $31.06 \mathrm{i}$ \\
\hline 3 & Manure $_{0}$ Urine $_{2}$ & $33.27 \mathrm{hij}$ & $2.77 \mathrm{hij}$ & $36.36 \mathrm{ghi}$ & $3.03 \mathrm{hi}$ & $33.06 \mathrm{hi}$ \\
\hline 4 & Manure $_{0}$ Urine $_{3}$ & $35.59 \mathrm{fgh}$ & $2.97 \mathrm{fgh}$ & 39.10 efg & 3.26 efgh & 34.56 efgh \\
\hline 5 & Manure $_{1}$ Urine $_{0}$ & $30.98 \mathrm{ij}$ & $2.58 \mathrm{ij}$ & $33.87 \mathrm{hi}$ & $2.82 \mathrm{i}$ & $31.52 \mathrm{i}$ \\
\hline 6 & Manure $_{1}$ Urine $_{1}$ & $34.68 \mathrm{ghi}$ & $2.89 \mathrm{ghi}$ & $38.01 \mathrm{fgh}$ & $3.17 \mathrm{gh}$ & $33.96 \mathrm{gh}$ \\
\hline 7 & Manure $_{1}$ Urine $_{2}$ & $37.32 \mathrm{defg}$ & $3.11 \mathrm{defg}$ & $41.24 \mathrm{def}$ & 3.44 defg & $35.69 \mathrm{defg}$ \\
\hline 8 & Manure $_{1}$ Urine $_{3}$ & $39.68 \mathrm{cde}$ & 3.31 cde & 43.43 cde & 3.62 cde & $37.08 \mathrm{cde}$ \\
\hline 9 & Manure $_{2}$ Urine $_{0}$ & $35.08 \mathrm{fgh}$ & $2.92 \mathrm{fgh}$ & $38.44 \mathrm{fg}$ & $3.20 \mathrm{fgh}$ & $34.23 \mathrm{fgh}$ \\
\hline 10 & Manure $_{2}$ Urine $_{1}$ & 35.93 efgh & 2.99 efgh & 39.61 efg & 3.30 efgh & 34.80 efgh \\
\hline 11 & Manure $_{2}$ Urine $_{2}$ & $39.05 \mathrm{def}$ & $3.25 \mathrm{def}$ & $42.92 \mathrm{de}$ & $3.57 \mathrm{def}$ & $36.70 \mathrm{def}$ \\
\hline 12 & Manure $_{2}$ Urine $_{3}$ & $43.19 \mathrm{bc}$ & $3.60 \mathrm{bc}$ & $47.41 \mathrm{bc}$ & $3.95 \mathrm{bc}$ & $39.07 \mathrm{bc}$ \\
\hline 13 & Manure $_{3}$ Urine $_{0}$ & 37.36 defg & $3.11 \mathrm{defg}$ & 40.81 defg & 3.40 defgh & 35.69 defg \\
\hline 14 & Manure $_{3}$ Urine $_{1}$ & $40.23 \mathrm{~cd}$ & $3.35 \mathrm{~cd}$ & $44.15 \mathrm{~cd}$ & $3.68 \mathrm{~cd}$ & $37.41 \mathrm{~cd}$ \\
\hline 15 & Manure $_{3}$ Urine $_{2}$ & $44.19 \mathrm{~b}$ & $3.68 \mathrm{~b}$ & $48.73 \mathrm{~b}$ & $4.06 \mathrm{~b}$ & $39.61 \mathrm{~b}$ \\
\hline 16 & Manure $_{3}$ Urine $_{3}$ & $50.78 \mathrm{a}$ & $4.23 \mathrm{a}$ & $55.76 \mathrm{a}$ & $4.65 \mathrm{a}$ & $42.99 \mathrm{a}$ \\
\hline
\end{tabular}

Note: Figures for the same treatment and column followed by the same letter were not significantly different in the $5 \%$ Duncan test.

The increasedof economic results can be seen from the increased of grainweight of plant ${ }^{-1}$ and grainweight ha ${ }^{-1}$. Increasing dosage of cow manure to $15 \mathrm{t} \mathrm{ha}^{-1}$ and cow urine $12 \%$ water content) significantly increased grainweight of plant $^{-1}$ and grainweight ha ${ }^{-1}$ (Table 6). The results of the regression analysis conducted on the oven dry weight ha-1 obtained a linear equation with the equation $\mathrm{Y}=2.049+7.16 \times 10^{-2}$ Manure $+1.26 \times 10^{-5} \mathrm{U}(\mathrm{R} 2=0.862 * *)$, while the relationship between dosage of cow manure and cow urine with grain weight ha ${ }^{-1}$ at $12 \%$ moisture content with the equation $\mathrm{Y}=2,242+7.9 \times 10^{-2}$ Manure $+1.39 \times 10^{-5} \mathrm{U}(\mathrm{R} 2=0.862 * *)$.

\section{CONCLUSION}

The single effect of cow manure improved soil physical properties by reducing bulk density, increasing water content and total pore space. Increasing the dosage of manure to $15 \mathrm{t} \mathrm{ha}^{-1}$ reduced the bulk density at harvest from 1.23 to 1.16 , increased soil water content from $31.11 \%$ to $35.17 \%$ and increased total soil pore space from $53.64 \%$ to $56.23 \%$.Increasing dosage of cow manure and bio urine improved soil chemical properties. N-total soil at harvest increased due to the interaction of sometimes fertilizer and cow bio-urine $0,17 \%$ in the combination treatment of cow manure dosage of $10 \mathrm{t} \mathrm{ha}^{-1}$ with cow bio-urine of 50,000 $1 \mathrm{ha}^{-1}$ compared without fertilization $(0.13 \%)$. C-organic soil at harvest increased due to the sole influence of cow manure and bio-urine. Increasing dosage of cow manure to $15 \mathrm{t} \mathrm{ha}^{-1}$ and cow urine urine to $75,000 \mathrm{l} \mathrm{ha}^{-1}$ increased the C-organic soil at harvest from $0.27 \%$ to $1.67 \%$ and from $0.75 \%$ to $1.18 \%$, respectively.Increasing the dosage of manure to $15 \mathrm{t} \mathrm{ha}^{-1}$ and cow's bio-urine to $151 \mathrm{ha}^{-1}$, still increased the growth and yield of Serayalocal maize. The relationship between dosage of cow manure and bio-urine of cow with the oven dry weight ha ${ }^{-1}$ and grain weight ha $^{-1}$ at $12 \%$ water content was linear with the equation $\mathrm{Y}=2.049+7.16 \times 10^{-2}$ Manure + $1.26 \times 10^{-5} \mathrm{U}(\mathrm{R} 2=0.862 * *)$ and $\mathrm{Y}=2.224+7.9 \times 10^{-2}$ Manure $+1.39 \times 10^{-5} \mathrm{U}(\mathrm{R} 2=0.862 * *)$. 


\section{ACKNOWLEDGMENT}

Infinite thanks the author conveyed to: the DG of the Indonesian Agency for Research and Development (IAARD); the director of the Indonesian Center for Assessment Institute of Agricultural Technology (ICAIAT), and the Headof Bali Assessment Institute of Agricultural Technology (BAIAT)forproviding funding, advice, encouragement, and suggestions of this research.

\section{REFERENCES}

[1] Suastika, D.K.S., Kasim, F., Sudana, W., Hendrayana, R., Suhariyanto, K., Gerpacio, R.V., Pingali, P.L. 2004. Maize in Indonesia. Mexico, D.F. : CIMMYT: Production Systems, Constrains and Research Priorities. $41 \mathrm{p}$.

[2] Muhammad, F., Akuba, R.H. 2005. Agropoliplant. Inovasi Membangun Pertanian. Innovation Forever, Innovation or Die. Gorontalo: Penerbit Balitbangpedalda Provinsi Gorontalo. 176 hal.

[3] Distan Prov. Bali dan Fak. Ekonomi Unud. 2005. Peluang Pasar Komoditas PertanianTanaman Pangan dan Hortikultura di Provinsi Bali. (laporan). Denpasar: Kerjasama Dinas PertanianTanaman Pangan Provinsi Bali dengan Fakultas Ekonomi Universitas Udayana. 65 hal.

[4] Pemprov. Bali. 2008. Programa Penyuluhan Sektor Pertanian Provinsi Bali. Denpasar: Pemerintah Provinsi Bali. 35 hal.

[5] Agung, I.G.A.M.S., Suprapto, Nurjaya, I.G.M.O. 2003. Pengaruh KerapaplantTanaman Jagung (Zea mays L.) dan Varietas Kacang Tanah (Arachwas hypogaea L.) terhadap Hasil Jagung dan Kacang Tanah dalam Swastem Tumpangsari di Lahan Kering. Jurnal Agritrop 22(1):8-13.

[6] BPP Gerokgak. 2009. Programa Penyuluhan Pertanian dan Peternakan Tahun 2009. (laporan). Balai Penyuluhan Pertanian (BPP) Gerokgak, Kabupaten Buleleng. 41 hal.

[7] Kuntyastuti, H., Sunarsedyono, Wasmail, C. 1989. Pengaruh Pupuk Organik dan Anorganik terhadap Pertumbuhan dan Hasil Jagung. Jurnal Penelitian Tanaman Pangan 3(1):25-31.

[8] Flaig, W. 1984. Soil Organic Matter as a Source of Nutrients. Organic Matter and Rice. Los Banos Laguna, Philippines: International Rice Research Institute. p. 73-92.

[9] Suprijadi, Abdulrachman, S., Juliardi, I., Pahim. 2002. Pemupukan Berimbang Pada Tanaman Padi di Lahan Sawah Irigasi dan Tadah Hujan. Prosiding Seminar Swastem Produksi Tanaman Pangan Berwawasan Lingkungan. Bogor: Pusat Penelitian dan Pengembangan Tanaman Pangan. Badan Penelitian dan Pengembangan Pertanian.

[10] Kuntyastuti, H., Rahmania, A.A. 2001. Pemanfaaplant Pupuk Alternatif Organik dan Anorganik pada Kedelai di Lahan Sawah. Prosiding Seminar Nasional Pengembangan Teknologi Pertanian dalam Upaya Optimalwasasi Potensi Wilayah Mendukung Otonomi Daerah. Pusat Penelitian dan Pengembangan Sosial Ekonomi Pertanian. Badan Penelitian dan Pengembangan Pertanian.

[11] BPTP Bali dan Bappeda Prov. Bali. 2007. Proses Membuat Bio Urin. (leaflet). Denpasar: Balai Pengkajian Teknologi Pertanian Bali bekerjasama dengan Bappeda Provinsi Bali.

[12] Negara, I.M.S., Simpen, Arsa, Diantariani, Miwada. 2007. Teknik Penampungan dan Fermentasi Air Kencing Sapi Bali di Desa Dauh Yeh Cani, Badung Menjadi Pupuk Organik Ramah Lingkungan. Denpasar: Universitas Udayana. 5 hal.

[13] Adijaya, I.N. 2009. Respon Bawang Merah Terhadap Pemupukan Organik di Lahan Kering. Cibinong: Makalah dwasampaikan pada Diklat Fungsional Peneliti Tingkat Pertama di Lembaga Ilmu Pengetahuan Indonesia, 4-21 Juli 2009.

[14] Soepardi, G. 1979. Sifat dan Ciri Tanah. Bogor: Departemen Ilmu Tanah. Fakultas Pertanian, IPB. 648 hal.

[15] Buckman, H.O., Brady, N.C. 1982. Ilmu Tanah. Jakarta: Terjemahan Soegiman. Penerbit Bhatara Karya Aksara. 788 hal.

[16] Gomez, A.K., Gomez, A.A. 1995. Prosedur Statwastik Untuk Penelitian. Jakarta: Universitas Indonesia Press. 698 hal.

[17] Suratmini, N.P. 2004. Pengaruh Dosis Pupuk Nitrogen dan Pupuk Kandang Sapi Terhadap Hasil, Kadar Gula Biji dan Kadar Protein Kasar Brangkasan Jagung Manwas (Zea mays saccharata Sturt). (teswas). Denpasar: Universitas Udayana.

[18] Muku, O.M. 2002. Pengaruh Jarak Plantam Antar Barwasan dan Macam Pupuk Organik Terhadap Pertumbuhan dan Hasil Tanaman Bawang Merah (Allium ascalonicum L.) di Lahan Kering. (teswas). Denpasar: Universitas Udayana.

[19] Agus, F., Yustika R.D., Haryati, U. 2006. Penetapan Berat Volume Tanah. Sifat FisikTanah dan Metode Analisisnya. Dalam Kurnia, U., dkk. (Ed.).Sifat Fisik dan Metode Analisisnya. Bogor: Balai Besar Penelitian dan Pengembangan Sumberdaya Lahan Pertanian. Hal. 25-34. 
[20] Syukur, A., Harsono, E.S. 2008. Pengaruh Pemberian Pupuk Kandang dan NMANURE Terhadap Sifat Kimia dan Fisika Tanah Pasir Pantai Samas Bantul. Jurnal Ilmu Tanah dan Lingkungan 8(2):138-145.

[21] Sirappa, M.P. 2002. Penentuan Batas Kritis dan Dosis Pemupukan N untuk Tanaman Jagung di Lahan Kering pada Tanah Typic Usthorthents. Jurnal Ilmu Tanah dan Lingkungan 3(2):25-37.

[22] Sutejo, M.M. 2002. Pupuk dan Cara Pemupukan. Jakarta: Penerbit Rineka Cipta. 177 hal.

[23] Poerwowidodo. 1992. Telaah Kesuburan Tanah. Bandung: Penerbit Angkasa. 275 hal.

[24] Syukur, A., Indah, N.M. 2006. Kajian Pengaruh Pemberian Pupuk Organik Terhadap Pertumbuhan dan Hasil Tanaman Jahe di Inceptwasol, Karanganyar. Jurnal Ilmu Tanah dan Lingkungan 6(2):124-131.

[25] Syukur, A. 2005. Penyerapan Boron oleh Tanaman Jagung di Tanah Pantai Pasir Bugel dalam Kaiplantnya dengan Tingkat Frekuensi Penyiraman dan Pemberian Bahan Organik. Jurnal Ilmu Tanah dan Lingkungan 5(2):20-26.

[26] Purnomo, J. 2005. Respons of Maize Variety in Low Irradiation. Jurnal Agrosains 7(1):86-93.

[27] Indradewa, D., Kastono, D., Soraya, Y. 2005. Kemungkinan Peningkaplant Hasil Jagung dengan Pemendekan Baplantg. Jurnal Ilmu Pertanian 12(2):117-124.

Citation: Made Jana Mejaya,et.al., "Effects of Organic Fertilizer on Soil Characters, Maize Growth and Grain Yield” International Journal of Research Studies in Agricultural Sciences (IJRSAS), 2020; 6(5), pp. 27 34, http://dx.doi.org/ 10.20431/2454-6224.0605004

Copyright: (c) 2020 Authors. This is an open-access article distributed under the terms of the Creative Commons Attribution License, which permits unrestricted use, distribution, and reproduction in any medium, provided the original author and source are credited. 